\title{
浅析初中语文教学中学生课外阅读的兴趣培养
}

修金平

吉林省松原市扶余市新万发镇中学

DOI:10.32629/jief.v2i6.1031

[摘 要] 对于现在的初中语文教学来说, 尤其是面对新课改后的教育环境, 对于初中学生的学习能力有了更高的要求, 仅仅依靠教材中的知 识并不能满足学生综合素质的培养。本篇文章通过对课外阅读在初中语文学习的重要性进行分析, 来探讨如何在语文教学中培养学生对于课 外阅读的兴趣。

[关键词] 初中语文教学; 课外阅读; 兴趣培养

中图分类号: G633.3 文献标识码: A

语文是初中教学中重要的一门学科, 是人文科目的一种, 通过对语 言文字的规范使用, 来为学生们开启文化艺术的精神世界。由于语文承 载着传承文化和发扬文化的特点, 对于我国的教育来说, 语文不管是在 任何教育阶段都有着重要的意义。对于初中语文教学来说, 语文的特点 具有基础性和工具性, 是学生学习其它学科的基础, 只有对语句有着充 分的理解能力, 才能提高在其它学科的学习效率, 为学生的将来奠定基 础。另外语文还具有实践性和应用性, 在生活中随处可见对语文的应用, 在与人的交流交往过程中, 都要依托语文的应用模式。另外, 在初中教 学中, 语文最主要的特性是思想性和开放性, 对于语文的学习是永无止 境的, 从诗词歌赋到文言文, 从故事阅读到议论时事, 都是语文中的一 部分, 所以在语文的学习中, 要特别注意学习方法, 做到有效的学习和 运用。除此之外, 在新课改的要求下, 还对语文的多样性有了一定的重 视, 不仅要求对于语文课堂上的学习, 还主张开辟 “第二课堂”, 引导 学生进行课外阅读的学习模式。

\section{1 课外阅读在初中语文教学中的重要性}

1.1 帮助学生更好的理解语文课文

由于语文教材的限制, 在课堂上的课文学习中, 学生对于这方面的知 识可能没有阅读的兴趣, 这就导致了学生在课堂上的参与度不高, 无法充 分的理解教学的内容。而课外书籍包罗万象, 有各种方面的知识, 学生可 以选择感兴趣的书籍进行阅读, 从阅读中提高对于课文的理解能力, 可以 充分应用到语文的学习中, 还可以提高学生对于语文的学习兴趣。

\section{2 培养学生的自主学习能力}

通过学生对课外书籍的阅读, 调动了学生对课余时间的分配, 使学 生养成良好的自主学习能力。将学生作为学习中的主体, 帮助学生树立 了自主学习的意识, 通过自己的兴趣找到学习的方向, 把控学习的进度, 这符合现阶段我国教育新形势下对于学生的学习能力要求, 为学生培养 了良好的学习习惯。

1.3 推动了语文教学的发展

学生通过对课外书籍的阅读提高了语文学习的能力, 提高了教师课 堂上的教学效率, 为语文教学提供了更广阔的发展空间, 使学生在语文 教学中获得了主动的权利, 不再是传统模式下的教学氛围, 把重点放在 了学生的思维能力和理解能力的培养, 使学生在学习的过程中可以提高 自身的创造性思维, 促进了课堂内外的学习氛围, 推动了语文教学的发 展进程。

\section{2 提升初中语文教学中学生课外阅读兴趣培养的措施}

2.1 从课堂教学中进行引申

对于初中学生的课外阅读中, 教师需要在课堂上对其进行点拨, 根 据教材的内容让学生进行相关的课外书籍内容。不要让学生的课外阅读 脱离了语文教学的根本, 从而使学生在阅读过程中无法获得对语文知识 的学习。语文教师在课堂上, 在讲授课文时, 应该充分调动学生的积极 性, 通过对教材的引申来完成对学生课外阅读兴趣的培养。例如, 在学
习《观沧海》时, 可以通过诗句向学生们展示诗词中所勾勒出来的大海 吞吐日月的壮丽景象来提高学生们对于当时历史背景的兴趣, 再向学生 介绍作者曹操的生平简介, 写出这种胸怀天下、气势磅礴的诗句的原因, 从而引导学生对于 《三国演义》的阅读兴趣。《三国演义》就是通过对 当时历史人物和故事的描写, 来反映了当时社会的矛盾和斗争, 概括了 时代的巨变, 塑造了一批叱咤风云的英雄人物。这种从课堂教学中的引 申既可以集中学生在课堂上的注意力又可以提高学生对于课外书籍的阅 读兴趣, 从而提高语文教学的教学效率, 提升学生的语文成绩。

2.2 为学生的兴趣阅读培养提供有利的条件

在平时语文教学过程中, 教师和学校要积极为学生的创造良好的课 外阅读条件和氛围。首先, 对于教师来说, 应该适当的减少课后作业的 布置情况, 对于语文课文考察理解的题目可以进行转移, 比如对于教材 中的课后题目留到答疑时间与学生共同进行探讨, 将部分时间挪用出来 供学生们进行课外书籍的阅读, 也可以在每周采取固定的课程时间来进 行课外书的阅读, 从而让学生获得课外阅读的时间, 才能帮助其培养阅 读兴趣。另外, 学校也应该注意在校园内建立图书馆或者阅读室, 为学 生的课外阅读创造相应的条件, 在图书馆中的图书也要进行适当的选择, 为学生选择合适的书籍进行阅读。同时, 学校可以为学生开展一些课外 阅读的活动, 在教师的鼓动下引导学生进行活动的参与, 在活动中可以 设置一些与课外书籍有关的知识问题, 通过设立奖项的制度来培养学生 对于课外阅读的兴趣。

\section{3 加强教师与学生的互动}

在语文教学的过程中, 可以通过加强教师与学生的互动来培养学生 的课外阅读兴趣。教师可以通过在平时与学生进行沟通来了解学生的具 体爱好, 再通过学生的爱好来给学生推荐一些课外书籍, 以此来帮助学 生完成课外阅读的兴趣培养, 只有从学生的角度入手, 才能对他们进行 有效的引导。同时, 教师也可以为学生推荐一些故事性和趣味性比较强 的图书作为学生课外阅读的引路砖, 实现学生在阅读能力的上兴趣培养。

\section{3 结语}

总而言之, 对于初中学生来说, 语文的学习是至关重要的, 在语文 的教学基础上培养学生对于课外阅读的兴趣, 可以提高学生的理解能力 和自主学习能力, 因此, 在平时的教学过程中, 教师和学校都要为学生 创造良好的课外阅读条件, 积极培养学生的阅读兴趣, 为提高学生的语 文成绩打下基础。

\section{[参考文献]}

[1]陈林.初中语文教学中学生阅读兴趣的培养——让阅读的园地开 满丰富的花朵[J].中国校外教育,2014(25):41.

[2]郑中华.初中语文教学中学生阅读兴趣的培养[J].读与写(教育教 学刊),2012,9(05):124.

[3] 林秋恋.中学语文文言文课堂教学模式探索 [J]. 考试周 刊,2020(78):33-34. 